\title{
Desulfonatronovibrio halophilus sp. nov., a novel moderately halophilic sulfate-reducing bacterium from hypersaline chloride-sulfate lakes in Central Asia
}

\author{
D. Y. Sorokin • T. P. Tourova • B. Abbas • \\ M. V. Suhacheva $\cdot$ G. Muyzer
}

Received: 10 February 2012/ Accepted: 22 March 2012/Published online: 10 April 2012

(C) The Author(s) 2012. This article is published with open access at Springerlink.com

\begin{abstract}
Four strains of lithotrophic sulfate-reducing bacteria (SRB) have been enriched and isolated from anoxic sediments of hypersaline chloride-sulfate lakes in the Kulunda Steppe (Altai, Russia) at $2 \mathrm{M} \mathrm{NaCl}$ and $\mathrm{pH}$ 7.5. According to the $16 \mathrm{~S}$ rRNA gene sequence analysis, the isolates were closely related to each other and belonged to the genus Desulfonatronovibrio, which, so far, included only obligately alkaliphilic members found exclusively in
\end{abstract}

Communicated by A. Oren.

The GenBank/EMBL accession numbers of the 16S rRNA gene sequences of the HTR strains are GQ922847, HQ157562, HQ157563 and JN408678; the dsrAB gene sequences of (halo)alkaliphilic SRB obtained in this study are JQ519392-JQ519396.

Electronic supplementary material The online version of this article (doi:10.1007/s00792-012-0440-5) contains supplementary material, which is available to authorized users.

\section{Y. Sorokin $(\bowtie) \cdot$ T. P. Tourova}

Winogradsky Institute of Microbiology, Russian Academy

of Sciences, Prospect 60-let Octyabrya 7/2,

117811 Moscow, Russia

e-mail: soroc@inmi.ru; d.sorokin@tudelft.nl

D. Y. Sorokin - B. Abbas · G. Muyzer

Environmental Biotechnology Group,

Department of Biotechnology, Delft University of Technology,

Delft, The Netherlands

M. V. Suhacheva

Bioengineering Centre, Russian Academy of Sciences,

Prospect 60-let Octyabrya 7/1, 117811 Moscow, Russia

Present Address:

G. Muyzer

Department of Aquatic Microbiology, Institute for Biodiversity and Ecosystem Dynamics, University of Amsterdam,

Amsterdam, The Netherlands soda lakes. The isolates utilized formate, $\mathrm{H}_{2}$ and pyruvate as electron donors and sulfate, sulfite and thiosulfate as electron acceptors. In contrast to the described species of the genus Desulfonatronovibrio, the salt lake isolates could only tolerate high $\mathrm{pH}$ (up to $\mathrm{pH} 9.4$ ), while they grow optimally at a neutral $\mathrm{pH}$. They belonged to the moderate halophiles growing between 0.2 and $2 \mathrm{M} \mathrm{NaCl}$ with an optimum at $0.5 \mathrm{M}$. On the basis of their distinct phenotype and phylogeny, the described halophilic SRB are proposed to form a novel species within the genus Desulfonatronovibrio, D. halophilus (type strain $\mathrm{HTR}^{\mathrm{T}}=\mathrm{DSM} 24312^{\mathrm{T}}=\mathrm{UNIQEM} \mathrm{U802}{ }^{\mathrm{T}}$ ).

Keywords Sulfate-reducing bacteria (SRB) ·

Desulfonatronovibrio · Hypersaline lakes · Halophilic

\section{Introduction}

Hypersaline intra-continental (athalassohaline) salt lakes represent an extreme type of habitats where halophilic prokaryotes are a dominant form of life (Oren 2002). The sulfur cycle is definitely active in the sediments of these lakes, judging from the presence of diverse population of halophilic sulfur-oxidizing bacteria (Sorokin 2008) and the apparent sulfidogenic activity manifested by the presence of high concentrations of $\mathrm{FeS} / \mathrm{HS}^{-}$in the top sediment layer and measurable activity of sulfate reduction, albeit at salinities much lower than salt saturation (Brandt et al. 2001; Sørensen et al. 2004; Waldron et al. 2007).

Our recent study on sulfidogenesis in anoxic sediments of hypersaline chloride-sulfate lakes in Kulunda Steppe (Altai, Russia) (Sorokin et al. 2012) demonstrated the presence of several groups of moderately halophilic SOB there, most of which were highly similar to the phylotypes found previously in the Great Salt Lake in Utah (USA) 


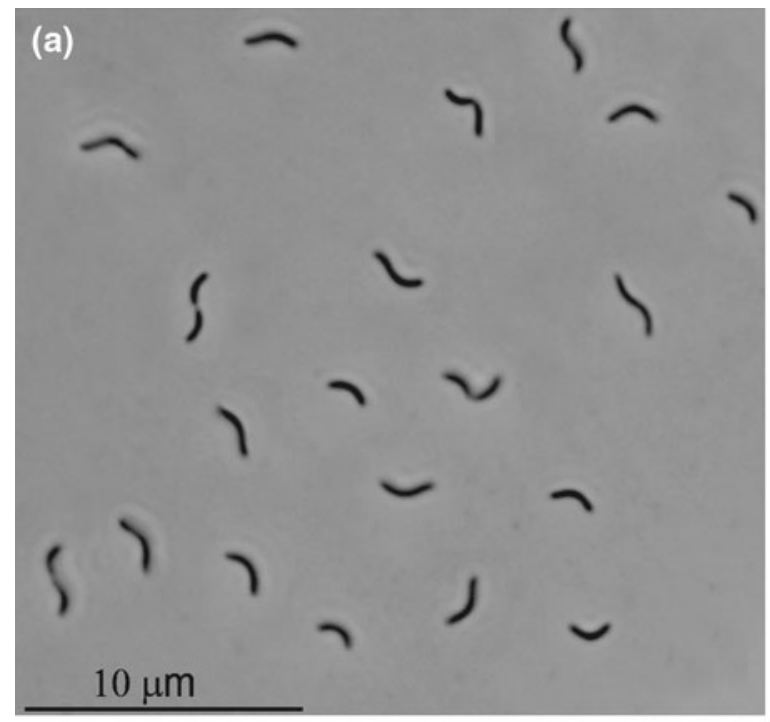

(c)

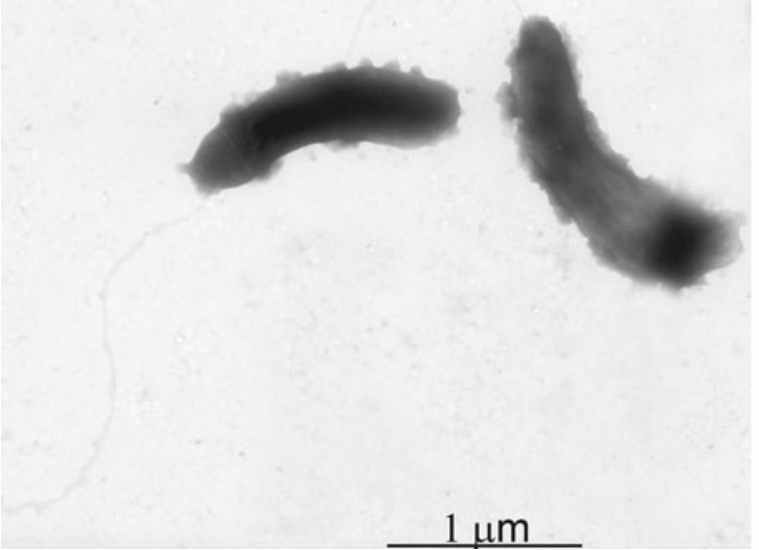

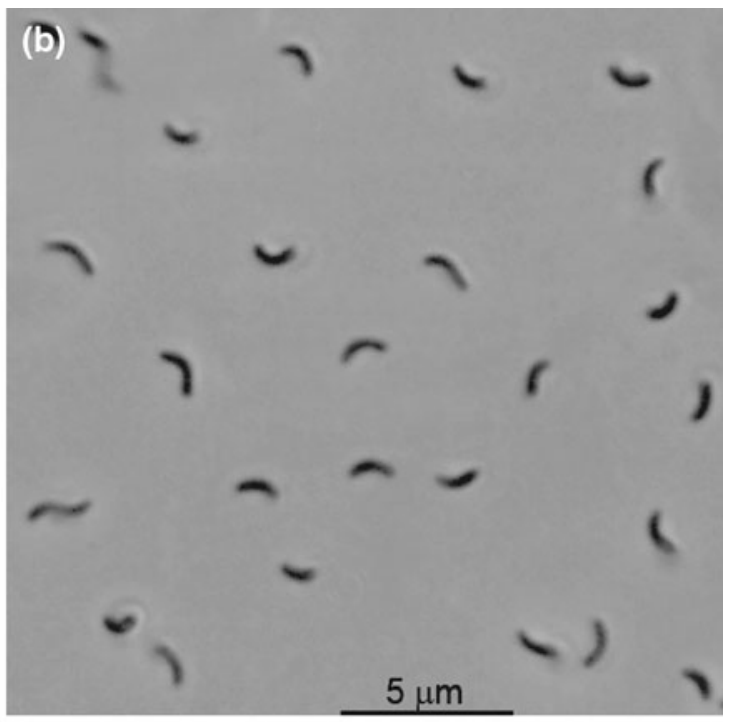

(d)

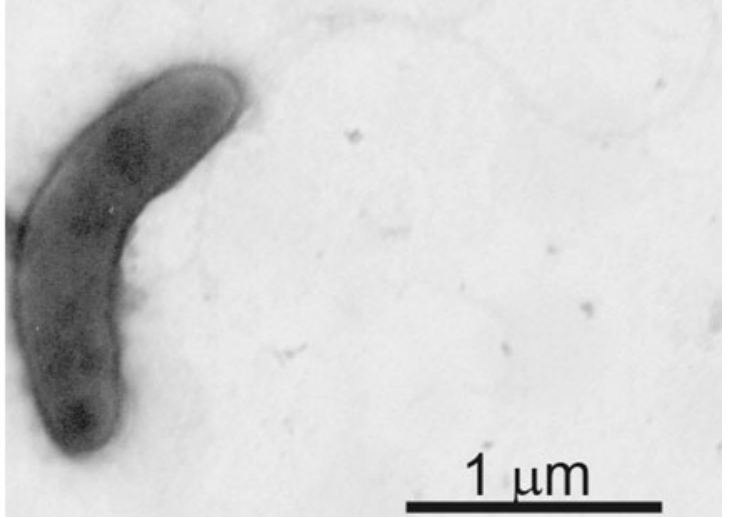

Fig. 1 Cell morphology of strains HTR1 (a, c) and HTR6 (b, d) grown at pH 8 and $1 \mathrm{M} \mathrm{NaCl}$ with formate and thiosulfate. a, b phase contrast microphotographs, $\mathbf{c}, \mathbf{d}$ electron microphotograph of positively stained cells

(Brandt et al. 1999, 2001; Jakobsen et al. 2006; Kjeldsen et al. 2007, 2010). There was, however, one exception, i.e., a group of four strains obtained directly or indirectly with formate as electron donor. These moderately halophilic $\mathrm{SRB}$, unexpectedly, were identified as members of the genus Desulfonatronovibrio - a typical representative of alkaliphilic SRB found previously exclusively in soda lakes (Zhilina et al. 1997; Sorokin et al. 2011).

In this report, we describe the properties of a novel halophilic member within the genus Desulfonatronovibrio, which is proposed to form a novel species D. halophilus.

\section{Methods}

Samples

Sediment samples of the top $10 \mathrm{~cm}$ layer were obtained in July 2010 from four hypersaline chloride-sulfate lakes located in the southern part of the Kulunda Steppe, southwestern Siberia (Altai, Russia). The lake brines had a $\mathrm{pH}$ range of 7.6-8.2, a salinity from 125 to $340 \mathrm{~g} \mathrm{l}^{-1}$, a sulfate content from 0.13 to $1.4 \mathrm{M}$ and an acid labile sulfides $\left(\mathrm{FeS}+\mathrm{HS}^{-}\right)$content from 0.3 to $17 \mathrm{mM}$. The individual sediments were mixed in equal proportions to make a single inoculum used to enrich for halophilic SRB.

\section{Enrichment and cultivation}

Enrichment and routine cultivation of halophilic SRB was performed at $28{ }^{\circ} \mathrm{C}$ on a mineral medium containing $2 \mathrm{M}$ $\mathrm{NaCl}$ buffered with $0.1 \mathrm{M}$ HEPES at $\mathrm{pH} 7.5$ as described previously (Sorokin et al. 2012). The $\mathrm{pH}$ dependence was examined at $\mathrm{Na}^{+}$content of $1 \mathrm{M}$, using the following filtersterilized buffers: for $\mathrm{pH}$ 6-8, 0.1 M HEPES and $\mathrm{NaCl}$ / $\mathrm{NaHCO}_{3}$; for $\mathrm{pH} 8.5-10$, a mixture of sodium bicarbonate/ sodium carbonate containing $0.1 \mathrm{M} \mathrm{NaCl}$. To study the 
a
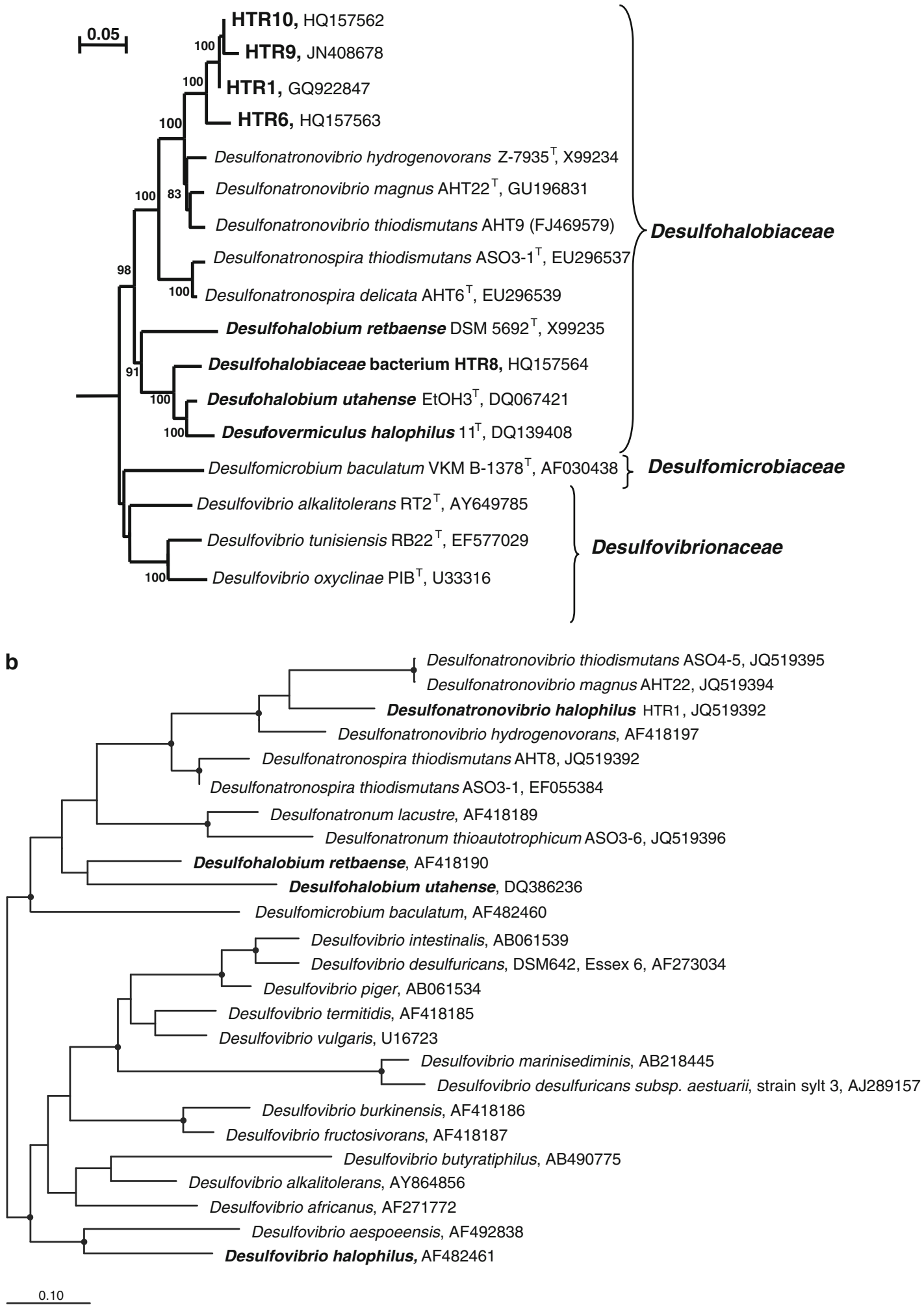

Fig. 2 Phylogenetic position of HTR strains within the order Desulfovibrionales based on 16S rRNA gene (a) and $d s r \mathrm{AB}$ gene (b) sequence analysis. Tree 16S rRNA gene tree topography and evolutionary distances are obtained by the neighbor-joining method with Jukes and Cantor distances. The numbers on the nodes indicate bootstrap values above $80 \%$. The halophilic representatives are in bold. The $d s r \mathrm{AB}$ gene-based tree topography and evolutionary distances are obtained by the Maximum Likelihood method, RAxML using 250 round of bootstrap ( $\geq 90 \%$ is indicated by a solid dot) and species AF418190 as a filter. In total 769 positions were used for calculation. All halophilic representatives are in bold 
(a)

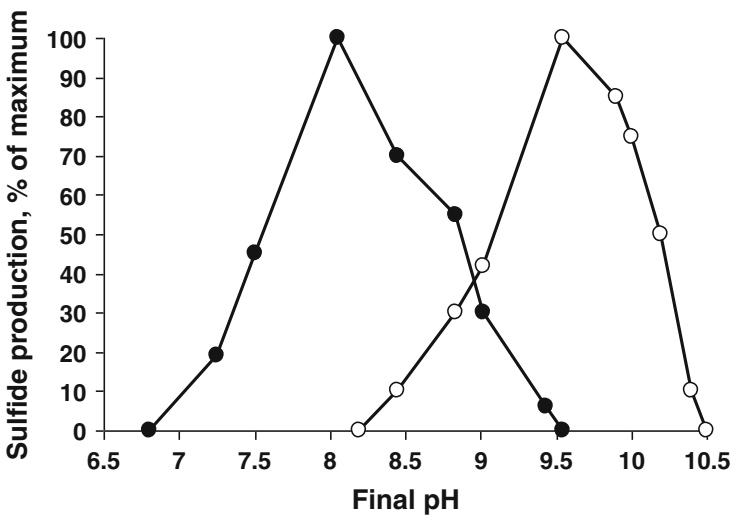

Fig. 3 Influence of $\mathrm{pH}$ at $1 \mathrm{M} \mathrm{NaCl}$ on growth (a) and sulfidogenic activity of resting cells (b) of strain HTR1 from salt lakes in comparison with Desulfonatronovibrio thiosulfatophilum AHT9 from soda lakes (grown at $0.6 \mathrm{M} \mathrm{Na}^{+}$). Both organisms were grown with

influence of salt concentration on growth, the HEPESbuffered media with $\mathrm{pH} 7.5$ containing 0.2 and $4 \mathrm{M} \mathrm{NaCl}$ were mixed in different proportions.

\section{Analytical procedures}

Sulfide was measured colorimetrically (Trüper and Schlegel 1964) after precipitation in $10 \%(\mathrm{w} / \mathrm{v}) \mathrm{Zn}$ acetate. Cell protein was determined according to Lowry et al. (1951) after removal of sulfide/thiosulfate and washing the cell pellet several times with $2 \mathrm{M} \mathrm{NaCl}$ containing $0.05 \mathrm{M}$ $\mathrm{HCl}$. Phase contrast microphotographs were obtained with a Zeiss Axioplan Imaging 2 microscope (Göttingen, Germany). For electron microscopy, the cells were negatively contrasted with $1 \%(\mathrm{w} / \mathrm{v})$ uranyl acetate containing $0.5 \mathrm{M}$ $\mathrm{NaCl}$ and observed in JEOL 100 (Japan) transmission electron microscope. Polar lipids were extracted from $50 \mathrm{mg}$ of freeze-dried cells with acidic methanol and the fatty acid methyl esters were analyzed by GC-MS according to Zhilina et al. (1997).

Genetic and phylogenetic analysis

The isolation of the DNA and determination of the $\mathrm{G}+\mathrm{C}$ content of the DNA were performed according to Marmur (1961) and Marmur and Doty (1962), respectively. For molecular analysis, the DNA was extracted from the cells using lysis in $1 \%$ (wt/vol) SDS/ $0.2 \mathrm{M} \mathrm{NaOH}$ at $60{ }^{\circ} \mathrm{C}$ and purified with the Wizard Preps Kit (Promega, USA). The nearly complete $16 \mathrm{~S}$ rRNA gene was obtained using general bacterial PCR primers 11f and 1492r (Lane 1991). The sequences were aligned with sequences from the GenBank using CLUSTAL $\mathrm{W}$ and the phylogenetic tree was (b)

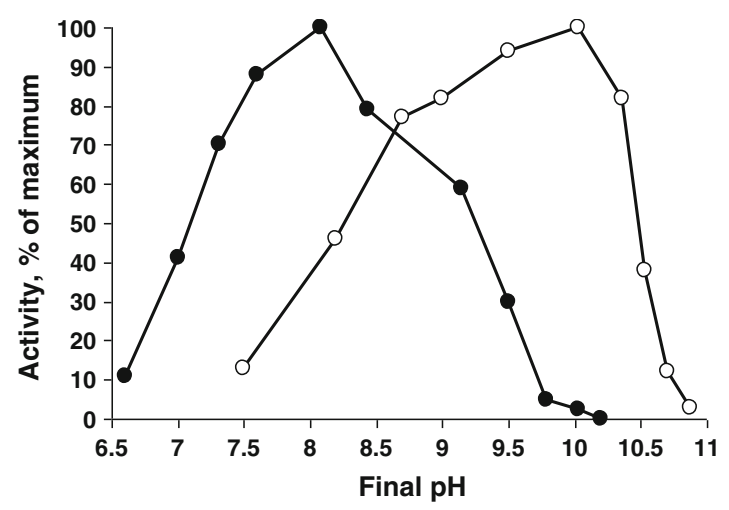

formate/acetate + thiosulfate and the washed cells were tested with formate + thiosulfate. Closed circles HTR1, open circles AHT9. The results represent average values obtained in from 2 duplicates

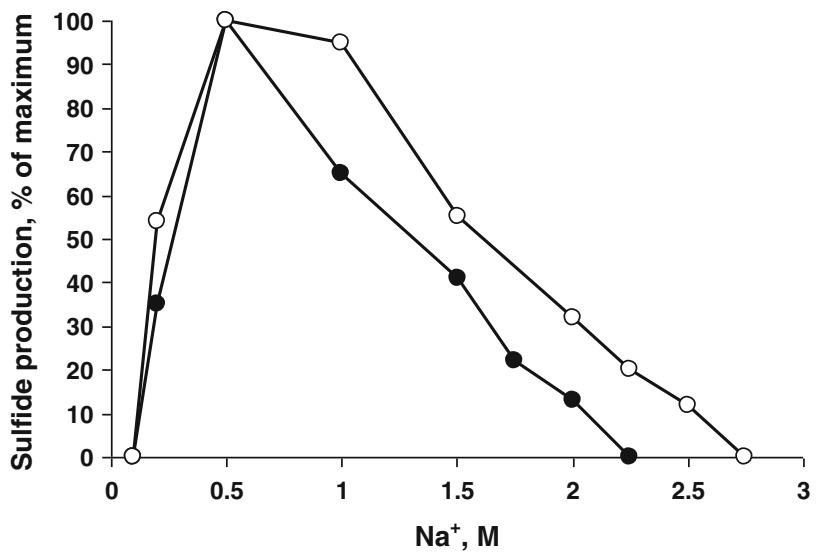

Fig. 4 Influence of $\mathrm{NaCl}$ at $\mathrm{pH} 8$ on growth (closed circles) and activity of washed cells (open circles) of strain HTR1 with formate as $e$-donor and thiosulfate as $e$-acceptor. The results represent average values obtained from 2 duplicates

reconstructed using either the neighbor-joining or maximum likelihood algorithms in the TREECONW program package (van de Peer and de Wachter 1994). The full dsrAB gene was amplified using the primers DSR-1Fmix and DSR4Rmix followed by agarose purification according to Miletto et al. (2008). The sequences were aligned using Codoncode aligner (CodonCode Corp., Dedham USA) software. The phylogenetic analysis was performed using ARB software (Ludwig et al. 2004). Sequences were aligned with complete length sequences of closest relatives from the order Desulfovibrionales obtained from updated $d s r \mathrm{AB}$ database (Loy et al. 2009) using the ARB FastAligner utility. The maximum likely hood method, RAxML (implemented in ARB), was used to calculate the resulting phylogenetic tree. 
Table 1 Phenotypic characteristics of the halophilic strain $\mathrm{HTR} 1^{\mathrm{T}}$ in comparison with the haloalkaliphilic representatives of the genus Desulfonatronovibrio

\begin{tabular}{|c|c|c|c|c|}
\hline Property & $\mathrm{HTR} 1^{\mathrm{T}}$ & Dsnv. hydrogenovorans ${ }^{\mathrm{a}}$ & Dnsv. thiodismutans ${ }^{\mathrm{b}}$ & Dnsv. magnus ${ }^{\mathrm{b}}$ \\
\hline Cell width $(\mu \mathrm{m})$ & 0.5 & 0.5 & $0.3-0.4$ & $0.6-0.8$ \\
\hline Autotrophy & - & - & \pm & - \\
\hline Fermentation and oxidation of pyruvate & + & - & + & + \\
\hline Growth by dismutation of thiosulfate or sulfite & - & Not shown & Thiosulfate, sulfite & Thiosulfate, sulfite \\
\hline pH range (optimum) & $7.2-9.4(8.0)$ & $8.0-10.2(9.6)$ & $8.5-10.5(9.5-10)$ & $8.5-10.5(10)$ \\
\hline Maximal salt tolerance & 2.0 & 2.0 & $2.0-3.0$ & 2.0 \\
\hline Predominant PLFA & $16: 0,17: 0,18: 0$ & $16: 0,18: 0$ & $18: 0,18: 1 \omega 7 \mathrm{c}$ & $\begin{array}{l}\text { i15:0, ai15:0, } \\
\text { i16:0, i17: } 1 \omega 8\end{array}$ \\
\hline $\mathrm{G}+\mathrm{C}(\mathrm{mol} \%)$ & 45.7 & 48.6 & $41.8-42.9$ & 43.0 \\
\hline
\end{tabular}

a Zhilina et al. (1997)

b Sorokin et al. (2011)

\section{Results and discussion}

Enrichment and isolation of pure cultures

Four positive anaerobic sulfidogenic enrichment cultures with either formate or ethanol as electron donor and sulfate or thiosulfate as electron acceptor at $2 \mathrm{M} \mathrm{NaCl}$ resulted in a domination of motile vibrio-shaped SRB (Fig. 1), which were further purified on the medium with formate by serial dilutions to extinction. Thus, four SRB strains were obtained designated HTR1, HTR6, HTR9 and HTR10. Strains HTR1 and HTR10 were obtained from an enrichment on $\mathrm{EtOH}+$ thiosulfate followed by purification on formate + thiosulfate; strain HTR6 was obtained from a direct enrichment with formate and sulfate and strain HTR9 from an enrichment on ETOH + sulfate followed by purification on formate + sulfate. The purity of the isolates was evident from the uniform cell morphology and from $16 \mathrm{~S}$ rRNA gene sequencing.

\section{Identification}

Phylogenetic analysis based on 16S rRNA gene sequencing showed that the HTR strains were closely related to each other (sequence similarity 97-99\%) and that they formed a novel cluster within the genus Desulfonatronovibrio (94-96\% sequence similarity to the 3 described species), which is a member of the family Desulfohalobiaceae, order Desulfovibrionales (Kuever et al. 2005) (Fig. 2a). From the four strains, HTR1, HTR9 and HTR10 were more closely related and HTR6 was somewhat more distant, although the phenotype of the isolates showed no obvious difference (see below). Phylogenetic analysis of the functional marker of SRB, the dsrAB gene, of strain HTR1 confirmed its affiliation to the type species of the genus Desulfonatronovibrio, D. hydrogenovorans (82\% nucleotide sequence similarity and $91 \%$ protein sequence similarity). However, the sequence similarity level of both markers indicated that the novel halophilic isolates belonged to a new species.

The analysis of cellular fatty acids in polar lipids of strains HTR1 and HTR6 showed highly similar profiles with a domination of saturated C16:0 and C18:0. Furthermore, a general similarity to the profiles of the previously described members of the genus Desulfonatronovibrio was also evident (Supplementary Table S1). However, a direct comparison may not be possible, since there was at least 2 $\mathrm{pH}$ units difference during the growth of halophiles and alkaliphiles.

Physiology

All HTR strains had a limited anaerobic respiratory metabolism typical for the genus Desulfonatronovibrio, restricted to utilization of $\mathrm{H}_{2}$, formate and pyruvate as electron donors with sulfate, thiosulfate and sulfite as electron acceptors. In contrast to the alkaliphilic species D. thiodismutans and D. magnus, but similar to the type species D. hydrogenovorans, the halophilic isolates were unable to grow by thiosulfate or sulfite dismutation. Growth with $\mathrm{H}_{2}$ and formate was only possible in the presence of acetate (i.e. lithoheterotrophically). Fermentative growth with pyruvate was not observed.

Influence of $\mathrm{pH}$ and sodium on growth and activity of strain HTR1

Strain HTR1 grew optimally in $\mathrm{NaCl}$ brines at $\mathrm{pH}$ 8, thus being a halophile, in contrast to the known obligately alkaliphilic representatives of the genus Desulfonatronovibrio from soda lakes. The $\mathrm{pH}$ range for growth was from 7.2 to 9.4 (Fig. 3a) which qualified HTR1 as an alkalitolerant halophile. Washed cells were active in a slightly 
wider $\mathrm{pH}$ range, but the sulfidogenic activity was almost completely inhibited at $\mathrm{pH} 10$ in a soda buffer optimal for the soda lake SRB (Fig. 3b). At an optimal pH of 8, strain HTR 1 grew at $\mathrm{NaCl}$ concentrations from 0.2 to $2 \mathrm{M}$ with an optimum at $0.5 \mathrm{M}$, and washed cells produced sulfide up to $2.5 \mathrm{M} \mathrm{NaCl}$ (Fig. 4). According to these data strain HTR1 is a moderate halophile.

Overall, the four halophilic lithotrophic SRB strains isolated from sediments of Siberian hypersaline salt lakes represent a novel, compact, phylogenetic group within the genus Desulfonatronovibrio clearly differentiating from its recognized species by the neutral $\mathrm{pH}$ optimum and inability to grow above $\mathrm{pH} 9.4$ (Table 1). We propose to assign these strains into a new species Desulfonatronovibrio halophilus.

Acknowledgments This work was supported by RFBR (10-0400152) to DS and by Ministry of Education and Science of Russian Federation (16.552.11.7035) to MS.

Open Access This article is distributed under the terms of the Creative Commons Attribution License which permits any use, distribution, and reproduction in any medium, provided the original author(s) and the source are credited.

\section{Appendix}

Description of Desulfonatronovibrio halophilus sp. nov.

(ha.lo'phi.lus Gr. n. hals salt; Gr. adj philos, loving; N.L. masc. adj. halophilus salt-loving, halophilic).

Cells are Gram-negative, vibrio-shaped, $0.4 \times 1-2 \mu \mathrm{m}$, and motile by a single polar flagellum. Strictly anaerobic and respiratory, using hydrogen, formate and pyruvate as $e$-donor and sulfate, thiosulfate and sulfite as $e$-acceptor. Pyruvate, thiosulfate and sulfite are not dismutated. Alkalitolerant with a $\mathrm{pH}$ range for growth between 7.2 and 9.4 and an optimum around 8 and moderately halophilic with a range from 0.2 to 2.0 $\mathrm{M} \mathrm{NaCl}$ (optimum at $0.5 \mathrm{M}$ ). Mesophilic, with a maximum temperature for growth at $45^{\circ} \mathrm{C}$ and an optimum at $37{ }^{\circ} \mathrm{C}$. The predominant fatty acids in the polar membrane lipids include 16:0, 18:0 and 18:1 $\omega 7 \mathrm{c}$. The $\mathrm{G}+\mathrm{C}$ content of the genomic DNA of strain HTR1 is $45.7 \mathrm{~mol} \%\left(T_{\mathrm{m}}\right)$. The type strain is $\mathrm{HTR}^{\mathrm{T}}\left(\mathrm{DSM} 24312^{\mathrm{T}}=\mathrm{UNIQEM} \mathrm{U802}{ }^{\mathrm{T}}\right)$. Isolated from sediments of soda lakes in south-western Siberia. The GenBank 16S rRNA gene sequence accession number of the type strain is GQ922847.

\section{References}

Brandt KK, Patel BKC, Ingvorsen K (1999) Desulfocella halophila gen. nov., sp. nov., a halophilic, fatty-acid-oxidizing, sulfate- reducing bacterium isolated from sediments of the Great Salt Lake. Int J Syst Bacteriol 49:193-200

Brandt KK, Vester F, Jensen AN, Ingvorsen K (2001) Sulfate reduction dynamics and enumeration of sulfate-reducing bacteria in hypersaline sediments of the Great Salt Lake (Utah, USA). Microbial Ecol 41:1-11

Jakobsen TF, Kjeldsen KU, Ingvorsen K (2006) Desulfohalobium utahense sp. nov., a moderately halophilic sulfate-reducing bacterium isolated from Great Salt Lake. Int J Syst Evol Microbiol 56:2063-2069

Kjeldsen KU, Loy A, Jakobsen TF, Thomsen TR, Wagner M, Ingvorsen K (2007) Diversity of sulfate-reducing bacteria from an extreme hypersaline sediment, Great Salt Lake (Utah). FEMS Microbiol Ecol 60:287-298

Kjeldsen KU, Jakobsen TF, Glastrup J, Ingvorsen K (2010) Desulfosalsimonas propionicica gen. nov. sp. nov., a novel halophilic sulfate-reducing member of the family Desulfobacteraceae isolated from sediment of Great Salt Lake (Utah). Int J Syst Evol Microbiol 60:1060-1065

Kuever J, Rainey FA, Widdel F (2005) Order II. Desulfovibrionales ord. nov. In: Garrity GM, Brenner DJ, Krieg NR, Staley JT (eds) Bergey's manual of systematic bacteriology, vol 2, part C, Class IV Deltaproteobacteria. Springer, New York, pp 926-936

Lane DJ (1991) 16S/23S rRNA sequencing. In: Stackebrandt E, Goodfellow M (eds) Nucleic acid techniques in bacterial systematics. Wiley, Chichester, pp 115-177

Lowry OH, Rosebrough NJ, Farr AL, Randall RJ (1951) Protein measurement with Folin phenol reagent. J Biol Chem 193:265-275

Loy A, Duller S, Baranyi C, Mußmann M, Ott J, Sharon I, Béjà O, Le Paslier D, Dahl C, Wagner M (2009) Reverse dissimilatory sulfite reductase as phylogenetic marker for a subgroup of sulfuroxidizing prokaryotes. Environ Microbiol 11:289-299

Ludwig W, Strunk O, Westram R, Richter L et al (2004) ARB: a software environment for sequence data. Nucleic Acids Res 32:1363-1371

Marmur J (1961) A procedure for isolation of DNA from microorganisms. J Mol Biol 3:208-214

Marmur J, Doty P (1962) Determination of the base composition of deoxyribonucleic acid from microorganisms. J Mol Biol 5:109-118

Miletto M, Loy A, Antheunisse AM, Loeb R, Bodelier PLE, Laanbroek HJ (2008) Biogeography of sulfate-reducing prokaryotes in river floodplains. FEMS Microbiol Ecol 64:395-406

Oren A (2002) Halophilic microorganisms and their environments. Kluwer AP, Dordrecht

Sørensen KB, Canfield DE, Oren A (2004) Salinity responses of benthic microbial communities in a solar saltern (Eilat, Israel). Appl Environ Microbiol 70:1608-1616

Sorokin DY (2008) Diversity of halophilic sulfur-oxidizing bacteria in hypersaline habitats. In: Dahl C, Friedrich CG (eds) Microbial sulfur metabolism. In: Proceedings of the international symposium on microbial sulfur metabolism 29.06.-02.07, 2006, Münster, Germany. Springer, Berlin, pp 225-237

Sorokin DY, Tourova TP, Detkova EN, Kolganova TV, Galinski EA, Muyzer G (2011) Culturable diversity of lithotrophic haloalkaliphilic sulfate-reducing bacteria in soda lakes and the description of Desulfonatronum thioautotrophicum sp. nov., Desulfonatronum thiosulfatophilum sp. nov., Desulfonatronovibrio thiodismutans sp. nov., and Desulfonatronovibrio magnus sp. nov. Extremophiles 15:391-401

Sorokin DY, Zacharova EE, Pimenov NV, Panteleeva AN, Tourova TP, Muyzer G (2012) Sulfidogenesis in hypersaline chloride-sulfate lakes of Kulunda Steppe (Altai, Russia). FEMS Microbiol Ecol 79:445-453

Trüper HG, Schlegel HG (1964) Sulfur metabolism in Thiorhodaceae. 1. Quantitative measurements on growing cells of Chromatium okenii. Antonie Van Leeuwenhoek 30:225-238 
van de Peer Y, de Wachter R (1994) TREECON for Windows: a software package for the construction and drawing of evolutionary trees for the Microsoft Windows environment. Comput Appl Biosci 10:569-570

Waldron PJ, Petsch ST, Martini AM, Nüsslein K (2007) Salinity constraints on subsurface archaeal diversity and methanogenesis in sedimentary rock rich in organic matter. Appl Environ Microbiol 73:4171-4179

Zhilina TN, Zavarzin GA, Rainey FA, Pikuta EN, Osipov GA, Kostrikina NA (1997) Desulfonatronovibrio hydrogenovorans gen. nov., sp. nov., an alkaliphilic, sulfate-reducing bacterium. Int J Syst Bacteriol 47:144-149 